\title{
Cerebral palsy dysphagia: a systematic review
}

\section{Disfagia na paralisia cerebral: uma revisão sistemática}

Edênia da Cunha Menezes ${ }^{(1)}$

Flávia Aparecida Hora Santos ${ }^{(1)}$

Flávia Lôbo Alves ${ }^{(1)}$

1) Universidade Federal de Sergipe, São Cristovão, SE, Brasil. Source of Financial Aid: FAPITEC

Conflict of interest: non-existent

Received on 03/19/2017 Accepted on 06/16/2017

Mailing address: Edênia Menezes Av. João Ouro n. 100, edf Canto Belo, bloco Sabia, apartameto 703 - São Cristóvão, SE, Brasil. CEP: 49095-180 E-mail: edeniamenezes@gmail.com

\section{ABSTRACT}

Cerebral palsy (CP) encompasses a group of definitive and non-progressive conditions, with a non-progressive character and its installation in neonatal period. Motor disorders caused by CP may lead to changes in swallowing, resulting in limitations in the activities that are attributed to non-progressive disorders that do not reach the developing child's brain. This article reviews the clinical aspects of dysphagia in CP and the treatments in the area. Only papers published in the period from 2009 to 2017 were considered, using a methodological strategy for electronic search in the databases SciELO-Brazil, Lilacs and Medline/ Pubmed. The present research analyzed 24 articles, regarding the year of publication, sample and instruments used, verifying that Speech Therapists and other staff involved in the improvement and rehabilitation of cognitive functions have provided better rehabilitation conditions, despite the need for more therapy and diagnostic studies.

Keywords: Cerebral Palsy; Swallowing Disorders; Risk Factors

\section{RESUMO}

A paralisia cerebral engloba um grupo de afecções definitivas e não progressivas no sistema nervoso central sem caráter progressivo e de instalação no período neonatal. Os distúrbios motores ocasionados pela paralisia cerebral podem acarretar alterações na deglutição ocasionando limitações de atividade que são atribuídas a distúrbios não progressivos que ocorrem no cérebro infantil em desenvolvimento. Esse artigo revisa os aspectos clínicos da disfagia na paralisia cerebral e as terapêuticas existentes na área. Foram considerados apenas os trabalhos publicados no período de 2009 a 2017, e utilizou-se como estratégia metodológica uma busca eletrônica nas bases de dados: SciELO-Brasil, Lilacs e Medline/ Pubmed. A presente pesquisa analisou 24 artigos, resumidamente, quanto ao ano de publicação, amostra e instrumentos utilizados, constatando que o Fonoaudiólogo e os demais profissionais envolvidos no aperfeiçoamento e reabilitação das funções cognitivas têm criado melhores condições de reabilitação, apesar da necessidade de mais estudos nas áreas de terapia e diagnóstico.

Descritores: Paralisia Cerebral; Transtornos da Deglutição; Fatores de Risco 


\section{INTRODUCTION}

Cerebral palsy (CP) is represented by a group of disorders characterized by altered movement, posture and tonus. The disorders are due to non-evolutionary damage of the central nervous system, which prevents the full development of this system still in the uterus, during childbirth or in the first years of life. The damage is not progressive and it weakens in a variable way the coordination of the muscular action, resulting in the child's inability to maintain postures and to perform normal movements, being able, with the passage of time, to have changes in its clinical manifestations. It is classified by the body location of the neuromotor impairment, and the most common are tetraparesis, hemiparesis and paraparesis, and by type of tonus and posture alteration: athetoid, ataxic, hypotonic, spastic (corresponding to about $80 \%$ of cases) and mixed ${ }^{1-3}$.

The major cause of $\mathrm{CP}$ is perinatal anoxia due to abnormal or prolonged labor. The second major cause is prematurity. Less frequently are prenatal infections such as rubella, toxoplasmosis, cytomegalovirus, and postnatal infections such as meningitis. Patients with CP suffer from decreased cerebral oxygenation, which affects areas of swallowing control ${ }^{4}$.

Motor palsies of cerebral palsy are often accompanied by disturbances of sensation, perception, cognition, communication and behavior, by epilepsy, and by secondary musculoskeletal disorders. They may lead to changes in swallowing as they change the anticipatory, preparatory, oral, pharyngeal and esophageal phases, causing limitations of activity that are attributed to non-progressive disorders that occur in the developing child's brain ${ }^{5}$.

People may have difficulties in motor actions, such as eating and swallowing, hindering hydration and adequate nutrition, which compromises nutritional status ${ }^{2,6}$.

The alimentary difficulties range from neurological immaturity to the interference of the mood state and their caregivers' preparation. Among the most frequently encountered difficulties are dysphagia for solids and liquids, regurgitations and vomiting, prolonged time to offer the meal and intestinal constipation. These manifestations are considered risk factors for eating disorders: by the motor alteration of the oropharyngeal dynamics; lack of understanding of the alimentary context and difficulty in the voluntary motor action of the oral phase, being able to alter the sequencing of the pharyngeal phase; and by the severity of pulmonary aspiration ${ }^{3}$.
Disturbances in the process of swallowing may cause problems in feeding. These disorders are called dysphagia. That can be, among other causes, secondary to neurological alterations that generate inadequate control of the oral, pharyngeal or esophageal swallowing phase. Eating difficulties may cause aspiration of food and fluids into the airways, which is the major cause of morbidity and mortality in $\mathrm{CP}^{7}$. Difficulties may develop or worsen in adulthood and changes in feeding and swallowing are suggested and adults, for example, using a feeding tube. It is necessary that caregivers and professionals be attentive monitoring the first symptoms of food difficulties. High digestive alterations may trigger nutritional deficits and problems in the growth curve, greater number of hospitalizations and the need for gastrostomy ${ }^{3,4}$.

In an attempt to avoid clinical and nutritional impairments, children with $\mathrm{CP}$ who present changes in swallowing are referred for phonoaudiological therapy in dysphagia, in order to promote greater functionality in the diet and to verify if the feeding route used is safe and efficient for each child ${ }^{8}$. The speech therapist, in his or her assessment, should be aware of all orofacial muscles and functions. The patient's posture and positioning during the evaluation were also guided ${ }^{4}$.

It is necessary the presence of an interdisciplinary team that is aware of these changes and capable of providing the appropriate treatment of these conditions, preventing the nutritional and health repercussions of these individuals. Changes in global growth, such as obesity and malnutrition, still represent challenges in the care of children with $\mathrm{CP}$, both for pediatricians and for specialized teams. These nutritional deficiencies may add to impairments in motor and cognitive development, socialization, psychological function, utilization of health services and the need for hospitalizations, and global health in individuals who already have all these spheres compromised ${ }^{9}$.

It is important to emphasize that, in addition to the changes in movement, it is necessary to investigate the presence of other disorders such as cognitive, visual, auditory, linguistic, sensory cortical, attention, wakefulness and behavioral abnormalities, epilepsy, hormonal dysfunctions, orthopedic problems, gastrointestinal and growth retardation. Children with $\mathrm{CP}$ may have gastrointestinal disturbances and eating difficulties that directly affect their growth and life quality. Virtually all individuals with CP have some degree of digestive or nutritional changes at some point in their lives, since the neurological connection with the 
digestive tract is of paramount importance. Therefore, a good relationship between speech therapy and the patient and his/her family is necessary to achieve the therapeutic objectives ${ }^{3}$. The objective of this article was to investigate the contribution and new findings of Speech Therapy and other professionals in improving clinical intervention and analysis, understanding the characteristics of swallowing changes in this population through a systematic literature review.

\section{METHODS}

Selection of studies, inclusion criteria and data extraction. For the descriptors, structured and bilingual vocabulary (English/Portuguese) - Descriptors in Health Sciences (DeCS) were used. Thus, the methodology adopted in this work was the systematic review, a study that serves to direct the development of projects, guiding future research based on existing research methods in the area of Hospital Speech-Language Pathology.

Only papers published in the period from 2009 to 2017 were considered, and an electronic search in the databases was used as methodological strategy: SciELO-Brazil and Medline/Pubmed. We used he following exclusion criteria: studies whose study population consisted of adults (Figure 1). Those who had dysphagia associated with cerebral palsy were included; and eating difficulties in cerebral palsy. In order to obtain the results, we used the following descriptors in Portuguese: Paralisia Cerebral e Disfagia, as well as the following crossings: Motricidade Orofacial e Fonoaudiologia and in English the following descriptors: Cerebral Palsy and Deglutition Disorders.

\begin{tabular}{|c|c|c|c|c|c|}
\hline DATABASE & FOUND & INCLUDED & $\begin{array}{c}\text { EXCLUDED } \\
\text { Because they did } \\
\text { not open }\end{array}$ & $\begin{array}{c}\text { EXCLUDED } \\
\text { Because they are } \\
\text { not related to the } \\
\text { theme }\end{array}$ & $\begin{array}{c}\text { TOTAL OF } \\
\text { ARTICLES }\end{array}$ \\
\hline SCIELO & 8 & 8 & 0 & 0 & 8 \\
\hline PUBMED & 203 & 15 & 4 & 183 & 16 \\
\hline \multicolumn{7}{|r|}{ TOTAL OF ARTICLES ANALYZE: 23 } \\
\hline
\end{tabular}

Figure 1. Criteria for identification of the study

In the search, we evaluated and selected only the articles that belonged to the proposed theme. The data of each of the potentially relevant articles for the systematic review were collected through a protocol record containing: eligibility criteria, method, type of study, type of interventions and outcomes measured and results obtained. The articles selected for analysis were those the presented level of evidence:

- Systematic reviews

- Controlled studies

- Intervention studies

It is worth noting that, according to the principles of the systematic review, only studies with levels of evidence 1 and 2 should be selected. Thus, this work was developed through the following methodological steps: initially the electronic selection happened; sorting the articles; then the analysis and classification based on the theme Dysphagia and Cerebral Palsy.

\section{LITERATURE REVIEW}

Thus, 23 papers met the criteria chosen in this study, and were selected. All of them were read in order to identify the year of publication, sample and instruments used (Figure 2).

The topic "absence of empirical material" appeared only in one article and refers to the outcome/benefit of the interventions and techniques used during feeding and swallowing in children with cerebral palsy. The article confirms that empirical data is needed and compared the oral sensory-motor interventions of 2 studies involving children with CP. The authors state that it is impossible to compare treatments that use different approaches, with different durations and intensity. Interventions during feeding may promote oral motor function, but they do not prove to be effective in feeding/nutrition and should be evaluated critically before being inserted into therapy ${ }^{10}$.

The topic "deglutition" appeared in 2 articles. In one of them, the authors sought to document the 


\begin{tabular}{|c|c|c|c|}
\hline STUDY & TYPE OF STUDY & METHODOLOGY & RESULTS \\
\hline $\begin{array}{l}\text { Haak e Peterson, } 2009 . \\
\text { Cerebral palsy and aging }\end{array}$ & Review & $\begin{array}{l}\text { Review showing epidemiological data, mortality, } \\
\text { motor aspects, life expectancy and life quality of } \\
\text { adults with CP. }\end{array}$ & $\begin{array}{l}\text { Because this research is totally informative for } \\
\text { professionals, families and people with CP. It } \\
\text { shows lack of evidence based on therapy and } \\
\text { for life quality in adults with CP. }\end{array}$ \\
\hline $\begin{array}{l}\text { González e Jiménez, } 2010 . \\
\text { Patología gastrointestinal } \\
\text { enniñosconparálisis cere- } \\
\text { bral infantil y otrasdiscapa- } \\
\text { cidades neurológicas }\end{array}$ & Review & $\begin{array}{l}\text { Analysis of the pathophysiology, diagnosis and } \\
\text { treatment of the patients' main nutritional and di- } \\
\text { gestive complications. }\end{array}$ & $\begin{array}{l}\text { All patients with CP have gastrointestinal symp- } \\
\text { toms or changes in their nutritional status at } \\
\text { some point of their lives. }\end{array}$ \\
\hline $\begin{array}{l}\text { Otapowicz, 2010. Dyspha- } \\
\text { gia in Children with Infantile } \\
\text { Cerebral Palsy }\end{array}$ & Cross-Sectional & $\begin{array}{l}\text { It evaluated } 67 \text { children with spastic cerebral pal- } \\
\text { sy, clinical and functional analysis of swallowing. }\end{array}$ & $\begin{array}{l}\text { It showed that more than } 50 \% \text { of the children } \\
\text { present dysphagia, being necessary the evalua- } \\
\text { tion and early stimulation of these children with } \\
\text { CP. }\end{array}$ \\
\hline $\begin{array}{l}\text { Furkim, 2009. The use of } \\
\text { cervical auscultation in tra- } \\
\text { cheal aspiration in children } \\
\text { with cerebral palsy }\end{array}$ & $\begin{array}{l}\text { Retrospective } \\
\text { Cohort }\end{array}$ & $\begin{array}{l}\text { Analysis of } 101 \text { medical records of children aged } \\
1 \text { to } 12 \text { years old with diagnosis of spastic quad- } \\
\text { riplegic cerebral palsy. }\end{array}$ & $\begin{array}{l}\text { Statistical results showed that there is a signifi- } \\
\text { cant relationship between positive cervical aus- } \\
\text { cultation and laryngeal penetration or aspiration } \\
\text { observed in videofluoroscopy of swallowing } \\
\text { and that negative cervical auscultation is more } \\
\text { associated with non-penetration/aspiration. }\end{array}$ \\
\hline $\begin{array}{l}\text { Hirata, 2012. Rehabilitation } \\
\text { of oropharyngeal dyspha- } \\
\text { gia in children with cerebral } \\
\text { palsy: A systematic review } \\
\text { of the speech therapy ap- } \\
\text { proach }\end{array}$ & Review & $\begin{array}{l}\text { Systematic review on rehabilitation of oropharyn- } \\
\text { geal dysphagia in children with CP, covering the } \\
\text { period from } 1977 \text { to } 2010 \text {, without exclusion by } \\
\text { language or nationality. }\end{array}$ & $\begin{array}{l}408 \text { total items found. Of these, } 310 \text { were } \\
\text { not repeated. Of the } 310 \text {, only } 22 \text { addressed } \\
\text { speech-language pathology in oropharyngeal } \\
\text { dysphagia in children with CP. }\end{array}$ \\
\hline $\begin{array}{l}\text { Lucchi, 2009. Incidência } \\
\text { de Disfagia Orofaríngea Em } \\
\text { Pacientes Com Paralisia } \\
\text { Cerebral Do Tipo Tetra- } \\
\text { paréticos Espásticos Insti- } \\
\text { tucionalizados }\end{array}$ & $\begin{array}{l}\text { Retrospective } \\
\text { Cohort }\end{array}$ & $\begin{array}{l}\text { A study of } 140 \text { patients with spastic tetraparesis } \\
\text { cerebral palsy from the Speech and Language } \\
\text { Pathology department of the Cruz Verde Associa- } \\
\text { tion of São Paulo, Brazil, gathering data from their } \\
\text { medical records about swallowing. }\end{array}$ & $\begin{array}{l}\text { There was presence of oropharyngeal dyspha- } \\
\text { gia in different degrees, and functional swal- } \\
\text { lowing was found in most patients ( } 40 \%) \text {. Of } \\
\text { the patients with functional swallowing and } \\
\text { mild dysphagia, the majority, } 65 \% \text { and } 50 \% \text {, re- } \\
\text { spectively. Of those with moderate dysphagia, } \\
66.7 \% \text { receive a diet in semi-liquid consistency, } \\
\text { and } 94.7 \% \text { of patients with severe dysphagia } \\
\text { make use of an alternative route of feeding. }\end{array}$ \\
\hline $\begin{array}{l}\text { Lustre, 2013. Temporal } \\
\text { measurements of oral } \\
\text { transit time in children with } \\
\text { cerebral palsy of different } \\
\text { levels motors and the rela- } \\
\text { tionship with the severity of } \\
\text { dysphagia }\end{array}$ & $\begin{array}{l}\text { Retrospective } \\
\text { Cohort }\end{array}$ & $\begin{array}{l}\text { Study carried out in the Speech-Language Pathol- } \\
\text { ogy and Audiology Department, Association of } \\
\text { Disabled Child Care (AACD in Portuguese), with } \\
50 \text { children with CP (mean age } 3.6 \text { years old). A } \\
\text { clinical speech-language evaluation of swallowing } \\
\text { was performed. }\end{array}$ & $\begin{array}{l}\text { The mean swallowing time was } 1.33 \text { seconds } \\
\text { for the liquid consistency and } 3.33 \text { seconds for } \\
\text { the pasty consistency. Significant difference } \\
\text { was found between groups for both consisten- } \\
\text { cies, with progressive increase in swallowing } \\
\text { time the greater the impairment of swallowing } \\
\text { function. }\end{array}$ \\
\hline $\begin{array}{l}\text { Araújo, 2013, Anthropo- } \\
\text { metric assessment of pa- } \\
\text { tients with cerebral palsy: } \\
\text { which curves are more ap- } \\
\text { propriate? }\end{array}$ & Cross-Sectional & $\begin{array}{l}\text { Study with } 187 \text { individuals with cerebral palsy, } \\
\text { evaluating anthropometric data, description of the } \\
\text { presence of dysphagia, constipation and respira- } \\
\text { tory infections. }\end{array}$ & $\begin{array}{l}\text { The weight of most individuals with dysphagia, } \\
\text { recurrent respiratory infections, and constipa- } \\
\text { tion was below the } 50^{\text {th }} \text { percentile, with percent- } \\
\text { ages of } 67 \%, 75 \% \text {, and } 72 \% \text {. }\end{array}$ \\
\hline $\begin{array}{l}\text { Arvedson, 2013. Feeding } \\
\text { children with cerebral palsy } \\
\text { and swallowing difficulties }\end{array}$ & Review & $\begin{array}{l}\text { Directed revision in dysphagia in children with ce- } \\
\text { rebral palsy: types of deficits, clinical and instru- } \\
\text { mental evaluation, management decision making } \\
\text { and evidence of intervention effectiveness. }\end{array}$ & $\begin{array}{l}\text { Children with CP have changes in swallowing } \\
\text { comprehensively and monitored over time. All } \\
\text { children deserve opportunities for oral feeding } \\
\text { as much as possible by analyzing the pulmo- } \\
\text { nary status and levels of oropharynx ability. }\end{array}$ \\
\hline $\begin{array}{l}\text { Araújo, 2012. Digestive } \\
\text { tract neural control and } \\
\text { gastrointestinal disorders } \\
\text { in cerebral palsy }\end{array}$ & Review & $\begin{array}{l}\text { Systematic review of MEDLINE, LILACS, Sci- } \\
\text { ELO and Cochrane Library databases from } 1997 \\
\text { to 2012. The terms searched for were: cerebral } \\
\text { palsy, dysphagia, gastroesophageal reflux disease } \\
\text { and gastrostomy. }\end{array}$ & $\begin{array}{l}\text { The most prevalent digestive disorders are dys- } \\
\text { phagia, gastroesophageal reflux disease and in- } \\
\text { testinal constipation, with consequent repetitive } \\
\text { respiratory infections and deleterious repercus- } \\
\text { sions on nutritional status. }\end{array}$ \\
\hline
\end{tabular}




\begin{tabular}{|c|c|c|c|}
\hline STUDY & TYPE OF STUDY & METHODOLOGY & RESULTS \\
\hline $\begin{array}{l}\text { Kuperminc, 2013. Nutri- } \\
\text { tional management of chil- } \\
\text { dren with cerebral palsy }\end{array}$ & $\begin{array}{l}\text { Retrospective } \\
\text { Cohort }\end{array}$ & $\begin{array}{l}\text { Study showing the evidences and the best prac- } \\
\text { tices around the nutritional management of chil- } \\
\text { dren with cerebral palsy (CP) with suggestions, } \\
\text { specificities regarding nutritional evaluation. }\end{array}$ & $\begin{array}{l}\text { The study can guide practitioners in making } \\
\text { decisions about feeding, nurturing, and rais- } \\
\text { ing these children with complex needs. A col- } \\
\text { laborative, family-centered, longitudinal, "big } \\
\text { picture" approach lays the groundwork for suc- } \\
\text { cessful management }\end{array}$ \\
\hline $\begin{array}{l}\text { Benfer, et al, 2014. Oro- } \\
\text { pharyngeal Dysphagia and } \\
\text { Gross Motor Skills in Chil- } \\
\text { dren With Cerebral Palsy }\end{array}$ & Cross-Sectional & $\begin{array}{l}\text { Population-based study. Children with a diagnosis } \\
\text { of cerebral palsy were evaluated by direct mea- } \\
\text { surements of OPD (Oral Motor Assessment Table, } \\
\text { Dysphagia Disorders Research) and observations } \\
\text { of suggestive signs of pharyngeal deficiency and } \\
\text { impaired salivary control (GMFM). }\end{array}$ & $\begin{array}{l}\text { The OPD was presented at all levels of gross } \\
\text { motor severity, through direct evaluations. This } \\
\text { highlights the need for proactive screening of } \\
\text { all children with CP, even with mild deficiency. }\end{array}$ \\
\hline $\begin{array}{l}\text { Benfer, et al, 2014. Oro- } \\
\text { pharyngeal dysphagia in } \\
\text { preschool children with } \\
\text { cerebral palsy: oral phase } \\
\text { impairments }\end{array}$ & Cross-Sectional & $\begin{array}{l}\text { Study on the prevalence and patterns of oropha- } \\
\text { ryngeal dysphagia (OPD) in pre-school children } \\
\text { with cerebral palsy (CP), and their association } \\
\text { with duration, frequency and efficiency of meals. } \\
\text { There were } 130 \text { children diagnosed with CP in 18- } \\
36 \text { months and } 40 \text { children with typical develop- } \\
\text { ment. }\end{array}$ & $\begin{array}{l}\text { The difficulty in cleaning }(70 \%) \text { and chewing } \\
(65 \%) \text { were the most common deficiencies } \\
\text { in solids; And the difficulty of sucking a glass } \\
(60 \%) \text { for fluids. }\end{array}$ \\
\hline $\begin{array}{l}\text { Erasmus, et al, 2012. Clini- } \\
\text { cal practice: swallowing } \\
\text { problems in cerebral palsy }\end{array}$ & Literature Review & $\begin{array}{l}\text { A review that describes important functional and } \\
\text { anatomical issues related to swallowing problems } \\
\text { in children with CP based on literature and expert } \\
\text { opinion. }\end{array}$ & $\begin{array}{l}\text { Children with cerebral palsy may have swallow- } \\
\text { ing problems with severe drool as one of the } \\
\text { consequences. Malnutrition and peneumonia } \\
\text { by recurrent aspiration may increase the risk } \\
\text { of morbidity and mortality }\end{array}$ \\
\hline $\begin{array}{l}\text { Silvério, et al, 2009. Indica- } \\
\text { dores da evolução do paci- } \\
\text { ente com paralisia cerebral } \\
\text { e disfagia orofaríngea após } \\
\text { intervenção terapêutica }\end{array}$ & $\begin{array}{l}\text { Retrospective } \\
\text { Cohort }\end{array}$ & $\begin{array}{l}\text { Medical records of patients who underwent } \\
\text { speech therapy for functional swallowing reha- } \\
\text { bilitation in the Speech and Language Pathology } \\
\text { Department in } 2004 \text { and } 2005 \text { were consulted. }\end{array}$ & $\begin{array}{l}\text { Most people were fed with special preparation, } \\
\text { before and after the intervention, occurring } \\
\text { restriction of solids and liquids in the second } \\
\text { moment. There was a decrease in the severity } \\
\text { of dysphagia, reduction of bronchopneumonia } \\
\text { and pulmonary mucus hypersecretion, weight } \\
\text { gain and reduction of suggestive signs of laryn- } \\
\text { gotracheal penetration and/or aspiration. }\end{array}$ \\
\hline $\begin{array}{l}\text { Silvério, et al, 2010. Paci- } \\
\text { ente com paralisa cerebral } \\
\text { coreoatetoide: evolução } \\
\text { clínica pós-intervenção }\end{array}$ & $\begin{array}{l}\text { Retrospective } \\
\text { Cohort }\end{array}$ & $\begin{array}{l}\text { This study aimed to verify the efficacy of the } \\
\text { therapeutic intervention in swallowing function } \\
\text { and in the clinical stability of children with choreo- } \\
\text { athetoid cerebral palsy (CP) with oropharyngeal } \\
\text { dysphagia. }\end{array}$ & $\begin{array}{l}\text { There was a reduction in the incidence of sug- } \\
\text { gestive signs of laryngotracheal penetration } \\
\text { and/or aspiration, comparing pre and post- } \\
\text { intervention moments. }\end{array}$ \\
\hline $\begin{array}{l}\text { Vianna, } 2011 . \text { Cerebral } \\
\text { palsy: analysis of swal- } \\
\text { lowing patterns before and } \\
\text { after speech therapy inter- } \\
\text { vention. }\end{array}$ & Cross-Sectional & $\begin{array}{l}\text { The present study aimed to analyze swallowing } \\
\text { patterns before and after speech-language inter- } \\
\text { vention in a group of children with Cerebral Palsy } \\
\text { who present Dysphagia }\end{array}$ & $\begin{array}{l}\text { A slight improvement in the swallowing pattern } \\
\text { was observed, which consequently brought a } \\
\text { better feeding pattern to the patients that were } \\
\text { evaluated and oriented. }\end{array}$ \\
\hline $\begin{array}{l}\text { Clancy, 2011. Longitudinal } \\
\text { changes in feeding among } \\
\text { children with cerebral palsy } \\
\text { Between the ages of } 4 \text { and } \\
7 \text { year }\end{array}$ & Cross-Sectional & $\begin{array}{l}\text { The study aimed to analyze feeding differences } \\
\text { among children with cerebral palsy. Feeding data } \\
\text { were collected from the parents' questionnaires at } \\
\text { 6-month intervals over } 30 \text { months. }\end{array}$ & $\begin{array}{l}\text { Significant differences were observed between } \\
\text { the severity groups for all feeding variables ex- } \\
\text { cept coughing and choking during meals. Only } \\
\text { in the variable coughing it showed significant } \\
\text { changes over time. }\end{array}$ \\
\hline $\begin{array}{l}\text { Nápolis, 2015. Esophageal } \\
\text { eosinophilia in pediatric } \\
\text { patients with cerebral palsy }\end{array}$ & $\begin{array}{l}\text { Cross-Sectional, } \\
\text { retrospective } \\
\text { cohort and } \\
\text { descriptive. }\end{array}$ & $\begin{array}{l}\text { The study evaluated pediatric patients' medical } \\
\text { records diagnosed with cerebral palsy and eo- } \\
\text { sinophilic esophagitis treated at a tertiary center } \\
\text { of pediatric gastroenterology from August } 2005 \text { to } \\
\text { August } 2013 \text {. }\end{array}$ & $\begin{array}{l}\text { Of } 131 \text { patients with cerebral palsy, } 7 \text { had a di- } \\
\text { agnosis of eosinophilic esophagitis in the study } \\
\text { period. The most frequent symptoms associ- } \\
\text { ated were recurrent vomiting and dysphagia. }\end{array}$ \\
\hline $\begin{array}{l}\text { Oliveira, 2015. Therapeutic } \\
\text { intervention and family ac- } \\
\text { ceptance in a case of child } \\
\text { with cerebral palsy }\end{array}$ & Case Study & $\begin{array}{l}\text { The objective of this study was to describe the } \\
\text { case of a 5-year-old child with chronic non- } \\
\text { progressive encephalopathy and dysphagia from } \\
\text { birth. }\end{array}$ & $\begin{array}{l}\text { In the videofluoroscopy, aspiration was ob- } \\
\text { served with a liquid consistency and not pasty. }\end{array}$ \\
\hline
\end{tabular}




\begin{tabular}{|c|c|c|c|}
\hline STUDY & TYPE OF STUDY & METHODOLOGY & RESULTS \\
\hline $\begin{array}{l}\text { Santos, 2014. Accuracy of } \\
\text { clinical swallowing evalu- } \\
\text { ation for oropharyngeal } \\
\text { dysphagia in cerebral palsy }\end{array}$ & Cross-Sectional & $\begin{array}{l}\text { UNESP, } 45 \text { individuals with NPCE and oropharyn- } \\
\text { geal dysphagia, } 28 \text { males and } 17 \text { females, from } 3 \\
\text { to } 19 \text { years old. They studied } 45 \text { individuals with } \\
\text { NPCE and oropharyngeal dysphagia, } 28 \text { males } \\
\text { and } 17 \text { females from } 3 \text { to } 19 \text { years old. The clini- } \\
\text { cal evaluation of swallowing used specific proto- } \\
\text { col and videofluoroscopy of swallowing. }\end{array}$ & $\begin{array}{l}\text { It was verified that the clinical phonoaudiologi- } \\
\text { cal evaluation of oropharyngeal dysphagia in } \\
\text { NPCE presents greater sensitivity than specific- } \\
\text { ity. It was verified that there was sensitivity of } \\
80.0 \% \text {, specificity of } 46.67 \% \text {, positive predic- } \\
\text { tive value of } 77.78 \% \text { and negative predictive } \\
\text { value of } 77.78 \% \text {. }\end{array}$ \\
\hline $\begin{array}{l}\text { Waugh, 2011. Adverse } \\
\text { events and health status } \\
\text { following botulinum toxin } \\
\text { type A injections in chil- } \\
\text { dren with cerebral palsy }\end{array}$ & Clinical Trial & $\begin{array}{l}\text { The objective of this study was to evaluate chang- } \\
\text { es in health status before and after, as well as } \\
\text { adverse events after injections of Botulinum toxin } \\
\text { type A (BoNT-A) in children with cerebral palsy } \\
\text { (CP). }\end{array}$ & $\begin{array}{l}\text { Data collected for the month prior to adminis- } \\
\text { tration of BoNT-A indicated that children with } \\
\text { CP had significant background morbidity. After } \\
\text { injection of BoNT-A, adverse events occurred in } \\
23.2 \% \text { of the children. All adverse events were } \\
\text { temporary and there were no deaths. }\end{array}$ \\
\hline $\begin{array}{l}\text { Marraca, 2009. Swallow- } \\
\text { ing in children with neuro- } \\
\text { logic disorders: clinical and } \\
\text { videofluoroscopic evalua- } \\
\text { tions }\end{array}$ & $\begin{array}{l}\text { Retrospective } \\
\text { Cohort }\end{array}$ & $\begin{array}{l}\text { Retrospective analysis of } 24 \text { speech-language } \\
\text { assessment protocols and medical records of } \\
\text { children of both sexes, referred for clinical and } \\
\text { videofluoroscopic evaluation of swallowing at } \\
\text { Hospital das Clínicas, Medical School of Ribeirão } \\
\text { Preto - State University of São Paulo, Brazil, from } \\
\text { January } 2001 \text { to June } 2005 \text {. }\end{array}$ & $\begin{array}{l}\text { There was a greater occurrence of inadequate } \\
\text { control of the food bolus. There was a statisti- } \\
\text { cally significant correlation between cervical } \\
\text { auscultation and the hyoid and larygeal excur- } \\
\text { sion, and laryngotracheal aspiration for liquid } \\
\text { and pasty consistencies. Conclusion: both pro- } \\
\text { cedures are important and complementary in } \\
\text { the diagnosis of dysphagia. }\end{array}$ \\
\hline $\begin{array}{l}\text { Kantarcigil, 2016. A tele- } \\
\text { health approach to con- } \\
\text { ducting clinical swallowing } \\
\text { evaluations in children with } \\
\text { cerebral palsy }\end{array}$ & Cross-Sectional & $\begin{array}{l}\text { It was tested the reliability of an asynchronous } \\
\text { model for the evaluation of dysphagia in children } \\
\text { with CP using a standardized clinical evaluation. } \\
\text { Material and methods: Sixteen children (age group } \\
6.9-17.5 \text { years old) were evaluated in three clin- } \\
\text { ics. }\end{array}$ & $\begin{array}{l}\text { Asynchronous clinical assessments of swal- } \\
\text { lowing using standardized tools have accept- } \\
\text { able levels of agreement with face-to-face as- } \\
\text { sessments and may be an alternative for chil- } \\
\text { dren with access. }\end{array}$ \\
\hline
\end{tabular}

Figure 2. Articles analyzed in the systematic review

prevalence and patterns of oropharyngeal dysphagia in pre-school children with cerebral palsy (CP), associating with feeding efficiency. In $93.8 \%$ of the children, oral phase deficiencies appeared in chewing and swallowing, and changes were associated with a decline in their gross motor skills. In the other paper, they report that the oral motor patterns of children with $\mathrm{CP}$ vary from person to person, and that alterations in oral motor function may generate a spectrum of disabilities at each stage of the swallowing process, resulting in malnutrition, dehydration, pulmonary aspiration and pneumonia ${ }^{4,11,12}$.

The theme oral motor function and therapeutic intervention appeared in 2 articles. In one of them, the authors concluded that oral sensory-motor therapy may be effective in promoting oral motor function, but may not be in promoting the efficiency of oral feeding, caloric intake and weight gain. In this study, the decrease in the presence of suggestive signs of pulmonary penetration and/or aspiration may be due to the guidelines given to the caregivers regarding posture, volume and a more secure food consistency, in addition to the speech-language therapy itself. Stimulation, handling and feeding training have promoted greater swallowing functionality $^{12}$. In the other paper, the orientation of caregivers on how to put the patient at the time of feeding is extremely necessary due to the need for adequate motor control for feeding 4 .

Among the articles that addressed dysphagia, 14 presented the evaluation of dysphagia and food intake in CPs. They described the evaluation process, which indicates important functional and anatomical issues related to swallowing problems in children with cerebral palsy.

One of the articles brought an evaluation of dysphagia through specific protocols collected during interviews and observation of the ingestion of different food consistencies. They used cervical auscultation and pulse oximetry, coughing or choking during or after swallowing, poor oral motor skills, delayed pharyngeal response, multiple swallowing, increased secretion or stridor in the upper airways during or after swallowing and rhythm of the respiratory system. They found that satisfactory food intake is limited and threatens the children's health due to factors such as neurological immaturity, interference of mood and preparation of caregivers, as well as the peculiarities of individuals with CP (difficulties of positioning, change in movement 
and deformities; epilepsy, dental alterations, cognitive and language delay that hinders the communication about hunger and food preferences, diets offered in paste consistency, making the meal monotonous and risk of loss of nutrients in its preparation, etc.).

The authors of another paper described the eating difficulties (dysphagia) in children with CP, the clinical and complementary evaluation process and the speech and language therapy, which aims to establish the positioning and types of utensils, food consistency, indication of the use of thickener and reduction of the fractionated volume that is offered in each food supply. In this article, dysphagia is characterized by the presence of signs such as cough or hypoxemia during or after feeding; nasal regurgitation; extraoral escape; poor oral motor coordination; delayed pharyngeal response to elucidate the reflex of swallowing; multiple swallowing; increased secretion in the airways; fatigue during or after feeding; stridor of fluid in the upper airways during or after feeding; apnea or dyspnea during feeding; respiratory rhythm modification; tearing of the eyes, throat clearing, grimaces; prolonged time for swallowing and meal intake (45-60 min.); presence of residues in the oral cavity; protrusion of the tongue; tilt of the head, opisthotonos, diplopia, halitosis.

One of the articles addressed the clinical phonoaudiological evaluation as an instrument of investigation in oropharyngeal dysphagia that, although it has variable accuracy and distinct reliability among examiners, may lead the clinician to value any sign of risk in an attempt to be more sensitive in the identification of silent laryngotracheal aspiration. They found that the clinical phonoaudiological evaluation of oropharyngeal dysphagia in Non-Progressive Chronic Encephalopathy (NPCE) is more sensitive than specificity and further studies are needed to identify clinical predictors of silent aspiration and to increase the specificity of this instrument in this population.

Another article aimed to verify the time of preparation and oral transit of the swallowing of children with cerebral palsy and to relate it to the degree of dysphagia severity and to the motor level, according to the Gross Motor Function Classification System. The mean swallowing time was 1.33 seconds for the liquid consistency and 3.33 seconds for the pasty consistency. It was found that the higher is the motor level of the group of children, the longer is the swallowing time for the liquid consistency and a significant difference was found between the groups for both consistencies, with progressive increase of the swallowing time the greater the impairment of the swallowing function. Oral transit time in children with cerebral palsy was higher and represented the severity of the dysphagia presented, demonstrating that the greater is the overall motor impairment presented, the longer is the oral transit time ${ }^{1,3,9,11,13-20}$.

The topic consequences of digestive manifestations was described in 7 articles. In them, it is confirmed that upper digestive alterations may trigger recurrent respiratory infections, insufficient nutritional intake, nutritional deficit in the growth curve, greater number of hospitalizations and the need for gastrostomy ${ }^{1,10,11,15,18-21}$.

The topic pulmonary complications/aspiration in children with $\mathrm{CP}$ was referred in 3 articles that addressed dysphagia and the risk of aspiration in children with cerebral palsy. Dysphagia and the potential pulmonary consequences and nutrition/malnutrition state cause stressful meal times. Thus, children with moderate to severe dysphagia require multiprofessional intervention due to gastrointestinal involvement, pulmonary involvement, nutrition/hydration, oral sensory-motor skills, behavioral issues and family interactions ${ }^{3,10,11}$.

Eosinophilia was the specific theme of an article. It addresses eosinophilic esophagitis in $\mathrm{CP}$ patients. This type of esophagitis is defined by symptoms of esophageal disorders, predominantly eosinophilic inflammation restricted to the esophagus and causing esophageal dysphagia. The early diagnosis of eosinophilic esophagitis is essential in CP patients and should be done carefully and should take into account the regular criteria, since the frequency of eosinophilic esophagitis in CP patients found in this study was high when compared to the presence of the same disease in the general population. Further studies are needed to establish a specific diagnosis and treatment in patients with cerebral palsy and esophageal eosinophilia ${ }^{21}$.

The topic related to speech and language intervention/rehabilitation was present in 10 articles that described a plan to provide guidance, research approach and treatment of swallowing problems in cerebral palsy. The educational actions are approached as being essential to favor the adherence to speechlanguage therapy, and aimed at the caregivers of dysphagic patients. They are associated with the therapeutic process, encompassing the awareness and training for caregivers, helping them deal with functional issues related to food, that is, oral handling, type of diet, utensils, mode of supply, posture, signs of difficulty and compensatory strategies. 
In one of the articles, the caregivers were oriented in relation to the daily maintenance of the stimulation, optimizing the therapeutic results. In the study involving children with NPCE and their caregivers, there was an improvement in the caregivers' knowledge and behavior regarding the feeding of their children, after the caregivers were submitted to an educational action aimed at the feeding of dysphagic children. The role of speech therapy has been described as being fundamental in the orientation, education of family members and caregivers, and in the therapy of these patients. One of the articles aimed to verify the indicators of evolution in the feeding function and in the clinical stability of children with spastic quadriplegic CP who underwent speech therapy for the rehabilitation of oropharyngeal dysphagia. It was observed an evolution in the alimentary function and improvement in the clinical stability of children undergoing speech therapy. Suggestive signs of tracheal laryngeal penetration and/or aspiration were reduced due to the guidelines given to caregivers regarding posture, volume and food safety consistencies, as well as speech and language practice, which, through stimulation, manipulation and training, promote greater swallowing functionality. After the intervention with the multidisciplinary team in dysphagia, according to the data of this study, there was a decrease in the severity of oropharyngeal dysphagia and the presence of suggestive signs of laryngotracheal penetration and/or aspiration, as well as greater clinical stability due to the decrease in episodes of bronchopneumonia, and weight gain.

Another study sought to measure the efficacy of speech therapy intervention within a multidisciplinary team in cases of oropharyngeal dysphagia in children with choreoathetoid cerebral palsy. This study showed that, because of the difference in overall motor impairment and better cognitive performance, although speech-language intervention may promote greater efficacy of the swallowing process, some children maintain the need to use the alternative feeding route, not only because of the risk, but because of the need for greater nutritional support, since oral feeding in these children usually requires more time and compensations.

Another article sought to identify existing rehabilitation methods in the area of dysphagia in cases of cerebral palsy, with emphasis on the search for research using the following neuropathological methods: Bobath, Rodolfo Castillo Morales, orofacial motor sensory therapy and continuing education. The article concluded that there are still few studies that cover the (re)habilitation of these children, regarding the treatment of oropharyngeal dysphagia ${ }^{22}$. In this research, only 22 publications were found, among 310 related to neurological diseases and swallowing disorders, which really focus on speech therapy. Among the articles found only 2 of them $(9 \%)$ are national, which shows a limited concern of Brazilian researchers in investigating the efficiency of methods of rehabilitation of oropharyngeal dysphagia in. CP children ${ }^{4,6,12-16,23,24}$.

\section{CONCLUSION}

Numerous recent discoveries of neuroscience about the development and processing of information in the brain have been contributing to the understanding of learning. The speech therapist and other professionals involved in the improvement and rehabilitation of cognitive functions have created better conditions for intervention and analysis. In view of the analyzed articles, the need for more research on clinical aspects and therapeutic proposals is more specific, the issues of pathological reflexes and neuropathology.

\section{REFERENCES}

1. González Jiménez D, Díaz Martin JJ, Bousoño García C, Jiménez Treviño S. Patología gastrointestinal en niños con parálisis cerebral infantil y otras discapacidades neurológicas. An. Pediatría. 2010;73(6):361:-6.

2. Haak P, Lenski M, Hidecker MJC, Li M, Paneth N. Cerebral palsy and aging. Dev. Med. Child Neurol. 2009;51(4):16-23.

3. Araújo LA, Silva LR, Mendes FAA. Digestive tract neural control and gastrointestinal disorders in cerebral palsy. J. Pediatr. 2012;88(6):455-64.

4. Vianna CIO, Suzuki HS. Cerebral palsy: analysis of swallowing patterns before and after speech therapy intervention. Rev. CEFAC. 2011;13(5):790-800.

5. Marrara JL, Duca AP, Dantas RO, Trawitzki LVV, Lima RAC, Pereira JC. Swallowing in children with neurologic disorders: clinical and videofluoroscopic evaluations. Rev Pró-Fono Atual. Cientif. 2009;20(4):231-6.

6. Hirata GC, Santos RS. Rehabilitation of oropharyngeal dysphagia in children with cerebral palsy: A systematic review of the speech therapy approach. Int. Arch. Otorhinolaryngol. 2012;16(3):396-9. 
7. Furkim AM, Behlau MS, Weckx LLM. The use of cervical auscultation in tracheal aspiration in children with cerebral palsy. Rev. CEFAC. 2009;11(4):624-9.

8. Clancy KJ, Hustad KC. Longitudinal changes in feeding among children with cerebral palsy Between the ages of 4 and 7 years. Dev. Neurorehabilitation. 2011;14(4):191-8.

9. Araújo LA, Silva LR. Anthropometric assessment of patients with cerebral palsy: which curves are more appropriate? J. Pediatr. 2013;89(3):307-14.

10. Arvedson JC. Feeding children with cerebral palsy and swallowing difficulties. Eur. J. Clin. Nutr. 2013;67:S9-S12.

11. Benfer KA, Weir KA, Bell KL, Ware RS, Davies PS, Boyd RN. Oropharyngeal dysphagia in preschool children with cerebral palsy: oral phase impairments. Res. Dev. Disabil. 2014;35(12):3469-81.

12. Benfer KA, Weir KA, Bell KL, Ware RS, Davies PS, Boyd RN. Oropharyngeal Dysphagia and Gross Motor Skills in Children With Cerebral Palsy. Pediatrics. 2014;131(5):1553-62.

13. Silvério CC, Henrique CS. Indicadores da evolução do paciente com paralisia cerebral e disfagia orofaríngea após intervenção terapêutica. Rev. Soc. Bras. Fonoaudiol. 2009;14(3):381-6.

14. Otapowicz D, Sobaniec W, Okurowska-Zawada B, Artemowicz B. Dysphagia in children with infantile cerebral palsy. Adv. Med. Sci. 2010;55(2):222-7.

15. Santos RRD, Sales AVMN, Cola PC, Jorge AG, Peres FM, Furkim AM et al. Accuracy of clinical swallowing evaluation for oropharyngeal dysphagia in cerebral palsy. Rev. CEFAC. 2014;16(1):197-201.

16. Erasmus $\mathrm{CE}$, van Hulst $\mathrm{K}$, Rotteveel JJ, Willemsen MAAP, Jongerius $\mathrm{PH}$. Clinical practice: swallowing problems in cerebral palsy. Eur. J. Pediatr. 2012;171(3):409-14.

17. Kuperminc MN, Gottrand F, Samson-Fang L, Arvedson J, Bell K, Craig GM et al. Nutritional management of children with cerebral palsy: a practical guide. Eur. J. Clin. Nutr. 2013;67(2):21-3.

18. Lucchi C, Flório CPF, Silvério CC, Reis TM. Incidência de disfagia orofaríngea em pacientes com paralisia cerebral do tipo tetraparéticos espásticos institucionalizados. Rev. Soc. Bras. Fonoaudiol. 2009;14(2):172-6.
19. Lustre NS, Freire TRB, Silvério CC. Temporal measurements of oral transit time in children with cerebral palsy of different levels motors and the relationship with the severity of dysphagia. Audiol. Commun. Res. 2013;18(3):155-61.

20. Kantarcigil C, Sheppard JJ, Gordon AM, Friel KM, Malandraki GA. A telehealth approach to conducting clinical swallowing evaluations in children with cerebral palsy. Research in Developmental Disabilities. 2016; 55:207-217.

21. Nápolis ACR, Alves FA, Rezende ER, Segunda GR. Esophageal eosinophilia in pediatric patients with cerebral palsy. Einstein. 2015;13(2):232-7.

22. O'Flaherty SJ, Janakan V, Morrow AM, Scheinberg AM, Waugh MCA. Adverse events and health status following botulinum toxin type $A$ injections in children with cerebral palsy. Dev. Med. Child Neurol. 2011;53(2):125-30.

23. Oliveira L, Valarelli LP, Caldas CAT, Nascimento WV, Dantas RO. Therapeutic intervention and family acceptance in a case of child with cerebral palsy. Rev. CEFAC. 2015;17(1):286-90.

24. Silvério CC, Henrique CS. Patient with choreoathetoid cerebral palsy: post therapeutic intervention. Rev. CEFAC. 2010;12(2):250-6. 